\title{
Effects of methodology and stakeholder disaggregation on ecosystem service valuation
}

\author{
Emma G. E. Brooks ${ }^{1,2}, \underline{\text { Kevin G. Smith }}^{2}$, Robert A. Holland $^{1}$, Guy M. Poppy $^{1}$ and Felix Eigenbrod $^{1}$
}

\begin{abstract}
Contingent valuation is one of the most commonly used methodologies utilized in ecosystem service valuation, thereby including a participatory approach to many such assessments. However, inclusion of nonmonetary stakeholder priorities is still uncommon in ecosystem service valuations and disaggregation of stakeholders is all but absent from practice. We look at four site-scale wetland ecosystem service valuations from Asia that used nonmonetary participatory stated preference techniques from a range of stakeholders, and compare these prioritizations to those obtained from the largest monetary assessments available globally, the Ecosystem Service Value Database (ESVD). Stakeholder assessment suggests very different priorities to those from monetary assessments, yet priorities between different sites remained broadly consistent. Disaggregation of beneficiaries in one site showed marked differences in values between stakeholders. Monetary values correlate positively with values held by government officers and business owners, but negatively with fishermen and women who are relying most directly on the wetland ecosystem services. Our findings emphasize that ecosystem service assessment, monetary or otherwise, must capture the diversity of values present across stakeholder groups to incorporate site scale management issues, particularly in relation to poverty alleviation.
\end{abstract}

Key Words: ecosystem services; participatory approach; poverty alleviation; stakeholders; valuation; wetlands

\section{INTRODUCTION}

Since the publication of the Millennium Ecosystem Assessment (MEA 2005) the provision of ecosystem services (ES) has been increasingly encouraged for consideration in policy and decision making (TEEB 2012). This has particular relevance to much of the developing world, where human impact on the environment is expected to accelerate with increased impetus for development. With a focus on human well-being and social development, the ES concept has the potential to address poverty alleviation in conjunction with ecological concerns (Tallis et al. 2008). ES assessment permits the environment to be placed within a development framework, and promotes the viewpoint that progression toward the Millennium Development Goals can be achieved alongside a context of conservation priorities (Sachs et al. 2009). A major focus of the ES literature is on economic valuation and the methodologies to best appraise this (Hein et al. 2006, Bateman et al. 2011, TEEB 2012). Economic values provide a commonly understood and comparable methodology to quantify the value of ES (Balmford et al. 2002, Farber et al. 2002), yet the use of monetary values in assessment also sets precedence to base policy on the economic outcomes. Because the concept of ES accounting acknowledges that poorer households face disproportionate losses from the depletion of ES (TEEB 2008), economic valuation could have negative consequences for those living in poverty if those ES on which they rely are not considered most financially valuable to society as a whole.

Participatory valuation techniques, which can be used to establish monetary or nonmonetary values, are intended to overcome these issues to reflect not only the biophysical but the cultural and societal benefits from ES, and there is a growing literature that emphasizes the role of stakeholder participation in the assessment process (Cowling et al. 2008, Reed 2008). Nonmonetary participatory techniques, however, are rarely seen to be used in valuation literature, with the most commonly applied mechanisms for stakeholder participation within ecosystem assessment being participatory "stated preference" techniques such as contingent valuation or revealed preference techniques (TEEB 2012). These are popular tools for providing monetary values for nondirect goods; indeed contingent valuation is the most widely used methodology within ES valuation (Graves et al. 2009).

The application and efficacy of these participatory valuation techniques is still debated (e.g., Skourtos et al. 2010). Participatory approaches are largely applied to one or few ES (e.g., Hein et al. 2006, Jenkins et al. 2010), or for a combined-service scenario (e.g., Zander and Garnett 2011, Kaffashi et al. 2012), and therefore do not provide a stakeholder comparison across the full suite of ES of relevance. This provides little opportunity for stakeholders to contribute to often complex policy or management decisions beyond an individual monetary bid or preference for a limited question (Chee 2004). Moreover, ES valuation tends to focus on assigning mean values derived for the affected society as a whole (Farber et al. 2002). Considered as one aggregated group with no discrimination of different beneficiaries of different ES, this framework is likely to limit the contribution of ES consideration to poverty alleviation (Daw et al. 2011).

Given the limited inclusion of stakeholders in most assessment processes, there is a lack of connection between the methodologies utilized (monetary valuation) and the drivers of the framework (human well-being and poverty alleviation). However, to date there have been few direct comparisons of monetary and nonmonetary methods, nor of the impact that disaggregating by different groups of stakeholders has on findings (Daw et al. 2011). We examine the relationship between values of a nonmonetary stated preference approach in four disparate sites in Asia and those derived from one of the largest databases of monetary values of ES ever compiled, the Ecosystem Service Value Database (ESVD; Van der Ploeg and de Groot 2010, de Groot et al. 2012). We also examine the extent

${ }^{1}$ University of Southampton, ${ }^{2}$ Global Species Programme, IUCN (International Union for Conservation of Nature) 
to which disaggregation of stakeholders at one site reflects the aggregated monetary and nonmonetary valuations, and discuss the implications of these findings for the use of ES valuation in decision making.

\section{METHODS}

\section{Site description and collection of primary data}

This research is part of a larger interdisciplinary project, Highland Aquatic Resources Conservation and Sustainable Development - HighARCS (http://www.higharcs.org). The project used an integrated approach to develop knowledge on the importance of aquatic resources at five highland sites in Asia. As part of the integrated site assessments, an ES valuation was performed at each site. This information was used alongside further data including biodiversity surveys and socioeconomic analyses to inform site-specific integrated action plans designed to enhance poor livelihoods and contribute to highland aquatic resource conservation and sustainable use at each site (see website for more details).

The data presented here are a comparison of the ES valuation element of the project from four of the five sites. The project sites fall within Shaoguan, China; Buxa, West Bengal, India; and Quang Tri and Son La, Vietnam (see Fig. 1). An outline of each site is given in Appendix 1.

Fig. 1. Map of HighARCS project sites.

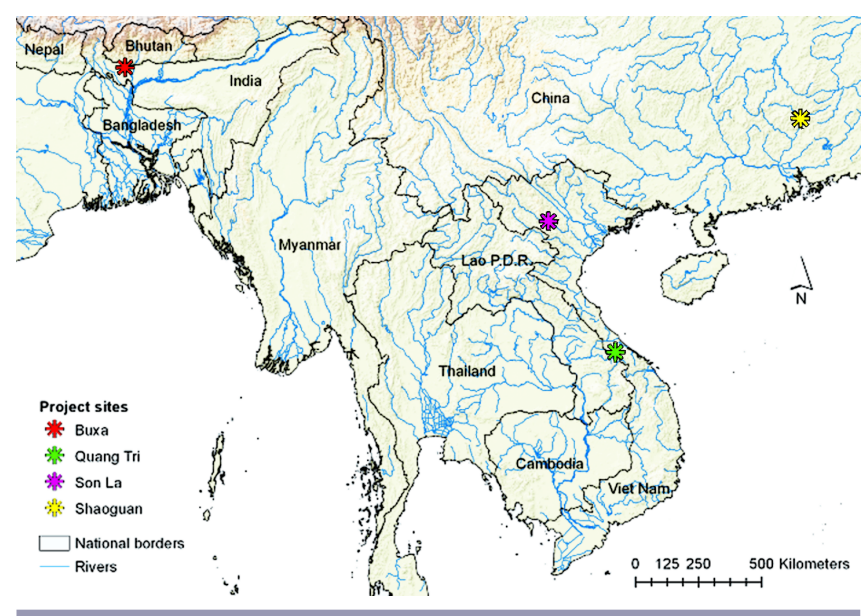

Following centralized group training, a nonmonetary participatory appraisal of ES was performed at each site by the in-country partner (see acknowledgments): Focus groups were held to identify the ES used by stakeholders specific to the site, and to determine groups of stakeholders relevant to the site. Details of the full suite of ES selected for each site can be found in Appendix 2. Individual interviews were then conducted across the range of stakeholders and participants were asked to give a score for each of the selected ES based on importance.

We compared the results of these nonmonetary participatory approaches with mean monetary values calculated from estimated pricings from the ESVD (Van der Ploeg and de Groot 2010). The ESVD has collated over 1350 value-estimates, and offers a useful tool to examine value importance of different ecosystem services in multiple biomes (de Groot et al. 2012). It represents an extensive scope of values from the literature, collated from different studies conducted at a range of scales, including local scale. We used values from the global database to obtain estimates of the monetary values for the services considered in this analysis because of a paucity of regionally relevant data. Given that the sites are geographically disparate across Southeast Asia this nonregion specific estimate is a generalized value for comparison across all sites. Mean values were calculated from all values in the database for the specific freshwater ES, except those not given as price/ha/year. Those estimated from a benefits transfer methodology were also excluded because benefits transfer studies do not collect new data, but rather use existing studies as the basis of valuation estimates. In line with de Groot et al. (2012), a purchasing power parity (PPP) conversion factor was applied to all values for the relevant year (WorldBank, http://data. worldbank.org/indicator/PA.NUS.PPP), and adjusted for inflation to the 2010 rate (Bureau of Labor Statistics, http://www. bls.gov/data/inflation calculator.htm).

In general, only ES identified and valued by all sites as part of the focus group process, and included within ESVD, were used in the comparison. In exception, Buxa did not consider hydropower or cultural value within their study. However, we included these services because of the high importance expressed at the other three sites.

Scores from the stakeholder interviews and values from monetary assessments were normalized onto the same $0-1$ scale, where 0 indicates a low value and 1 a high stakeholder or monetary value. At each site scores were normalized using min-max normalization; the minimum response score was subtracted from each response score, which was then divided by the range of scores for that site. As a result, the highest response score was converted to 1 , and the lowest response score was converted to 0 . A mean value per service was then calculated from the normalized scores to produce a nonmonetary value for each ES at each site (hereafter referred to as participatory values). Monetary values are a normalization of the mean monetary value for each service from the ESVD (hereafter referred to as monetary values).

\section{Comparisons between sites}

Because of the differences in methodologies of valuation, values between monetary and participatory values were not compared directly but instead focused on how relative rankings varied between sites. Spearman's rho nonparametric correlations were used to quantify these relative rankings, both for intersite comparisons, and to compare ranks of services between the monetary values and the normalized nonmonetary values for each site. This methodology follows the practice of previous studies in which mean scores have been compared directly (e.g., Rouquette et al. 2009). However, this alone does not account for the variation surrounding these means. Therefore $95 \%$ confidence intervals were generated for Spearman's rho by bootstrapping the data: Each pair of site (and ESVD) data sets were randomly sampled with replacement to create corresponding sample data sets the same size as the originals. Spearman's rho was then calculated between each pair of sampled data sets. This was then repeated 10,000 times per pair of sites, from which $95 \%$ confidence intervals could be calculated. A correction for distribution bias from within the sample was applied using the bias-corrected and accelerated method (BCa; Haukoos and Lewis 2005). All calculations were carried out in $\mathrm{R}$ 3.0.1. 


\section{Disaggregation of ES valuation by stakeholder type}

In addition to examining differences in ES values between sites, we also analyzed concordance in ES valuations between stakeholder groups in one site. As stated, each in-country partner identified their own stakeholders and did not divide stakeholders into the same groups. We therefore focused individual stakeholder analysis only on data from Shaoguan because they identified a good cross-section of widely applicable stakeholders, with a minimum sample size of 13 per stakeholder group. Participants represented four distinct stakeholder groups; government officers, business owners, farmers, and fishermen and fisherwomen (hereafter referred to as fishers). Farmers and fishers from the site are considered rural poor, with fishers being more dependent on direct resources from the land (Yiming et al. 2010). Many of the fishers are described as subsistence communities, with the poorest households relying most directly on aquatic resources. ES scores from the stakeholder groups were compared against monetary values as above.

\section{RESULTS}

\section{Comparisons between sites}

The normalized responses of the importance of each ES to each site, aggregated across all groups of stakeholders, and the mean monetary values for each ES are shown in Figure 2. There are marked differences between the range of scores from monetary values, compared to the consistently high participatory values from any of the sites. The value of water supply is more than double that of the next most monetarily valued service, flood control, which in turn is more than double of the next most valuable service, water treatment. In contrast, the participatory values assigned to different services are broadly similar. Difference in scores of ES between sites are relatively small, with a spread varying from 0.16 between sites for the value of fisheries, and 0.38 for the value of water supply.

Correlations between participatory valuations of sites vary, but broadly correlate with each other exhibiting medium to strong

Fig. 2. Normalized scores and standard error of ecosystem services of mean stakeholder perception values from four sites in Asia, and normalized mean monetary valuation. Lines have been added to help visualize the differences in rank of the services within each site, compared to the monetary valuation.

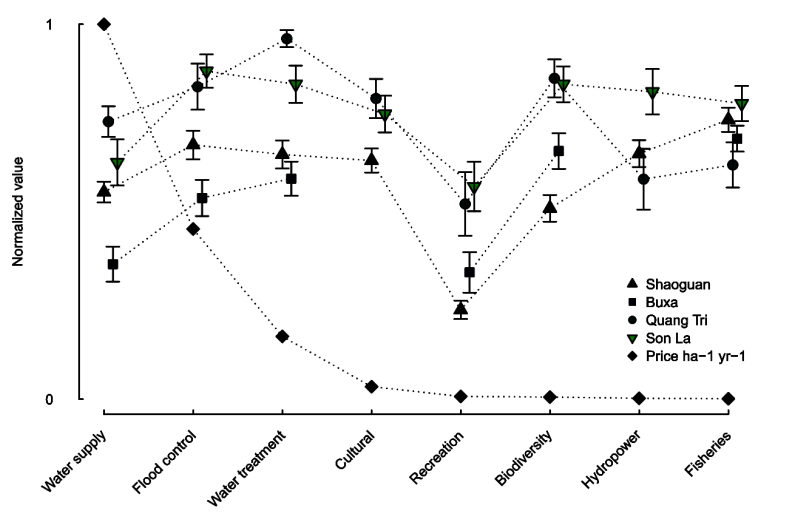

correlations (Table 1). The exception to this is between Shaoguan and Quang Tri. By contrast, there is little congruence between the rankings of ES from participatory values at each site versus the monetary values in all cases except Buxa, which shows a moderate negative correlation.

Table 1. Spearman's rho correlations and BCa 95\% confidence intervals between valuation scores of freshwater ecosystem services by monetary assessment and stakeholder values at four sites in Asia.

\begin{tabular}{llcc}
\hline \hline \multicolumn{2}{l}{ Valuation sources } & Rho & BCa 95\% CI \\
\hline Monetary & Shaoguan & -0.21 & $-0.55-0.02$ \\
Monetary & Buxa & -0.66 & $-0.94--0.54$ \\
Monetary & Quang Tri & 0.40 & $-0.12-0.62$ \\
Monetary & Son La & 0.04 & $-0.38-0.60$ \\
Shaoguan & Buxa & 0.60 & $0.26-0.83$ \\
Shaoguan & Quang Tri & 0.07 & $-0.38-0.40$ \\
Shaoguan & Son La & 0.49 & $0.19-0.90$ \\
Buxa & Quang Tri & 0.37 & $0.06-0.77$ \\
Buxa & Son La & 0.46 & $0.03-0.60$ \\
Quang Tri & Son La & 0.71 & $0.48-0.98$ \\
\hline
\end{tabular}

\section{Disaggregation of ES valuation by stakeholder type}

Disaggregation of beneficiaries in Shaoguan showed that there is large variation in the values that different groups of stakeholders place on ES. Male and female responses in Shaoguan were highly correlated (Spearman's Rho $=0.78$, df $=21, \mathrm{P}<0.001$ ) and therefore not separated for the stakeholder disaggregation analyses.

Correlation between the rankings scored by different stakeholder groups and the monetary values from ESVD show a high degree of variation (Table 2). Moderate to strong positive correlations are found between monetary values from ESVD and the participatory values of government officers and business owners. ESVD values have no correlation with those of farmers, and there is a moderate negative correlation between monetary values and participatory values of fishers. The participatory values of government officers also strongly positively correlate with business owners and farmers, whose values also positively correlate with each other. The values of farmers and fishers also positively correlate. Value scores of different stakeholder groups are presented in Figure 3, showing a marked difference again in breadth between monetary scores and participatory scores for all ES excluding water supply. The similarity of the normalized scores between stakeholders differs by ES, with a spread varying from 0.08 between stakeholders for recreation value, and 0.51 for water supply.

\section{DISCUSSION}

Values placed on freshwater ES across four disparate rural sites were broadly similar when measured by participatory assessments, but differed markedly when compared to globally derived monetary values of the same services. Disaggregation of beneficiaries at one site shows that generalized monetary valuation is likely to be a poor reflection of the values farmers and fishermen place on freshwater ES, but broadly correlate with 
the values placed on these resources by business owners and government officials.

Table 2. Spearman's rho correlations and BCa 95\% confidence intervals between valuation scores of freshwater ecosystem services by monetary assessment and different stakeholder groups in Shaoguan, China.

\begin{tabular}{llcc}
\hline \hline \multicolumn{2}{l}{ Valuation sources } & Rho & BCa 95\% CI \\
\hline Monetary & Government & 0.55 & $0.14-0.81$ \\
Monetary & Business & 0.72 & $0.45-0.93$ \\
Monetary & Farmer & 0.23 & $-0.31-0.63$ \\
Monetary & Fisher & -0.52 & $-0.74--0.48$ \\
Government & Business & 0.74 & $0.43-0.98$ \\
Government & Farmer & 0.71 & $0.35-0.98$ \\
Government & Fisher & -0.07 & $-0.41-0.06$ \\
Business & Farmer & 0.60 & $0.32-0.98$ \\
Business & Fisher & -0.07 & $-0.30-0.21$ \\
Farmer & Fisher & 0.46 & $0.05-0.84$ \\
\hline
\end{tabular}

Fig. 3. Normalized scores and standard error of ecosystem services of mean stakeholder perception values from Shaoguan, China, and normalized mean monetary valuation. Lines have been added to help visualize the differences in rank of the services within each site, compared to the monetary valuation.

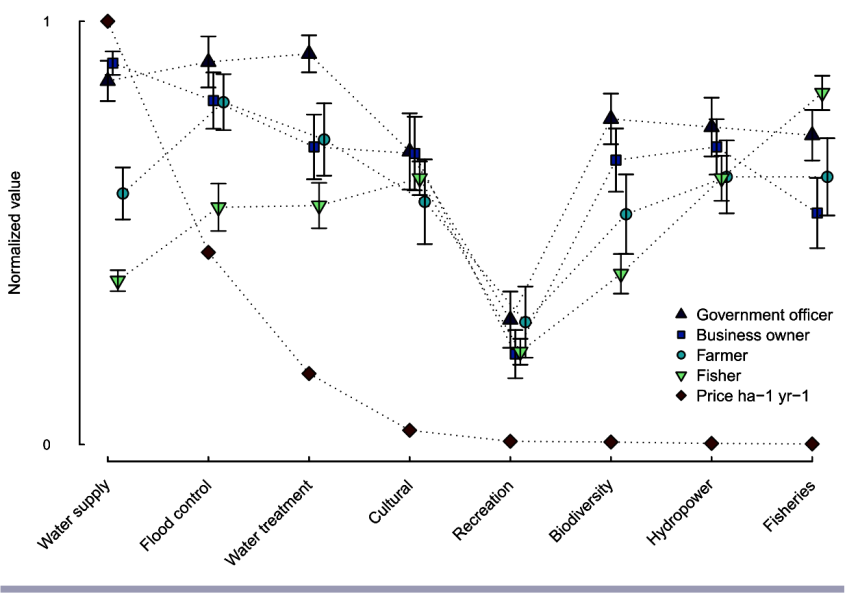

Stakeholders with differing local sensitivities, cultural backgrounds, and geographical locations might be expected to attach differing values to ES (Hein et al. 2006), yet despite the situational differences there is remarkably little difference between the values scored at sites in the current study. Given that the participants at sites considered here were asked to identify priority ES, it is unsurprising that all ES are scored reasonably highly, and a greater range of scores would be expected had a strict set of ES been tested. Nonetheless, the small inter- and intra-site variation found indicates a similarity of values for the ES considered held by stakeholders across a range of sites. This supports the strength and robustness of the participatory approach used here as a valuation method.

The implied similarities between sites are more strongly supported when comparing the priorities based on the rank order of participatory value means. Given that this work has been conducted as part of a large consortium project, the congruence between sites is encouraging. All project partners were given the same methodological training and instruction, but it has been carried out by different teams in different countries, on wetland sites that vary in their issues. Each site identified its own priorities and stakeholders, yet the ES valuations are remarkably concordant, showing that even across different countries, values for ES are similar at the community level.

A comparison of normalized values from a monetary perspective suggests a disparity between values garnered by a nonmonetary participatory approach and those projected from a monetary approach. If multiple wetland ES were valued to a similar degree to each other in monetary terms it would be entirely plausible that they would well match the participatory scores once normalized. Instead we find quite a steep decline in monetary values, indicating that a few wetland services have high monetary value while the rest have little monetary value, which is in contrast to the participatory values. Coupled with this the differences in rank orders suggest an incongruence of prioritizations of ES between the two methodologies. These results emphasize the need to understand and incorporate nonmonetary values to fully inform environmental management and decision making (Martín-López et al. 2007).

Critically, the findings of the study show a disaggregation of stakeholder views and suggest that the values held by those relying most directly on wetland ES (here the fishers, followed by the farmers) differ most widely from those predicted by monetary valuation. These results are perhaps unsurprising, yet are nonetheless extremely important given the implications on equity, in particular within a poverty alleviation framework, or when assessing ES whose beneficiaries include a range of stakeholders including vulnerable groups.

Coupled with the correlations of prioritizations expressed by both government officers and business owners with monetary values, it is clear that it is vital to consider that the opinions of decision makers (here represented by government officers and business owners) may not concur with those stakeholders that are most directly dependent upon the ES. Commonly in assessments where stakeholders are considered only a subset of stakeholders are included, or the perceptions of all stakeholders are amalgamated together, despite the expectation that different stakeholder groups would hold different values for the same ES (Vermeulen and Koziell 2002, Daw et al. 2011). The correlation in our study between the monetary valuations and the stakeholders that are most likely to be influential in decision making (here, government officers and business owners) highlights the disparity of representation by standard monetary valuations for all stakeholders, and especially the poor. In particular the government officers would be expected to represent a general public value which may downplay interests of specific groups. Although government officers in this study do correlate well with business owners and farmers, there is no correlation with the fishers, the most vulnerable group.

As stated, locally explicit participatory values have been compared with generalized monetary rankings from multiple scales, and localized valuation are unlikely to reflect global values because of generalization error (Plummer 2009). However, given 
the lack of congruence between stakeholder groups, it is unlikely that local monetary valuation would suitably reflect all groups, and it is interesting to see that even nonregion specific generalized monetary rankings have such strong correlation with business owners, the stakeholder group expected to be most influenced by monetary concerns. In turn this suggests that monetary valuation supports and represents the interests of businesses over that of local communities, and although a potentially useful tool, in some contexts may not be representative in a poverty alleviation framework, which should be carefully considered in any valuation process.

It is likely that the large disparity in values, monetary or otherwise, that different groups of stakeholders in Shaoguan placed on ES represent differences in the spatial scales at which stakeholders value ES (Hein et al. 2006, TEEB 2012). The purpose of the majority of valuation assessments is to inform management plans but these are likely to be at a larger scale of consideration than site-specific issues such as those explored in this project. For instance for freshwater the basin or catchment level scale is increasingly considered the most useful management unit for inland waters (e.g., IUCN 2000, Collares-Pereira and Cowx 2004, Vigerstol and Aukema 2011), which would not relate well to considerations at the community-level. In addition, a lack of data on most ES in most regions means that datasets such as the ESVD are likely to be used in valuation assessments, which, as we have shown, is unlikely to reflect the priorities of the poorest rural stakeholders.

Our results add to the literature showing that ES valuation assessments must disaggregate stakeholders not only to represent the entire range or dependencies and benefits from the system, but also to consider the benefits at multiple scales (Hein et al. 2006, Martín-López et al. 2007). For example, fisheries production is monetarily the least valuable of the ES considered, yet was consistently scored highly at the sites, with stakeholders at Shaoguan and Buxa scoring it as the most valuable ES provided. Although in monetary terms fisheries have relatively little importance for society as a whole, for some that live close to these wetlands fish are paramount to their subsistence and livelihoods and often act as an emergency resource when other livelihoods options fail (Béné et al. 2009). If decision making is based on monetary assessment to wider society alone, the importance of this ES at the local scale to the over 60 million people in developing countries dependent on freshwater fisheries (Dugan et al. 2010) is potentially ignored. Government managed sites have been shown to be managed for higher monetary value than communitymanaged sites (Hick et al. 2009), which is unlikely to suit the interests of local livelihood dependence. The comprehension of ES and natural capital currently struggles to incorporate the considerable worth of nonfinancial benefits, particularly where this benefit is felt by only a subset of stakeholders.

Participatory assessment can be cheaply and easily undertaken (Springate-Baginski et al. 2009). Some limitations of other participatory approaches (e.g., Skourtos et al. 2010) can be mitigated using a nonmonetary methodology as used here, because it does not require a financial value input, and any and all ES can be considered. This approach can broaden the valuation process beyond easily mapped ES, such as water provision and carbon sequestration data, and allows for the consideration of the full range of ES relevant to the study, and at the same scale, without the bias of capital prioritization. The methodology incorporates participation into the valuation process, which increases uptake and success of resulting recommendations within communities, particularly those in least developed countries (Christie et al. 2012). Unsurprisingly, the slight differences not only in valuation but also in ranking between the sites (Fig. 2, Table 1) indicate that benefits transfer is unlikely to be an appropriate application of this methodology, although it is of note that the two sites with the strongest correlation were between the two closest sites, Quang Tri and Son La, both located in Vietnam.

In summary, our results provide important additional evidence that conclusions on ES assessments for poverty alleviation cannot be drawn unless the considerations of target poor groups are incorporated (Daw et al. 2011). It is unlikely that either stated preference or monetary valuations in isolation are enough to fully inform an ES assessment that includes poorer households among its dependents, but an appropriate integration of both approaches would lead to better informed decision making. To properly consider the importance of services and to inform policy decisions it is important to adopt a more comprehensive approach that disaggregates stakeholders and considers importance for societal groups whose interaction with systems operates at differing scales. Applying an assessment methodology that includes multiple stakeholder priorities will maximize the beneficiaries of an ecosystem service approach.

Responses to this article can be read online at: http://www.ecologyandsociety.org/issues/responses. $\mathrm{php} / 6811$

\section{Acknowledgments:}

The authors would like to thank the field teams and researchers from of the HighARCS project that through their research provided data for this paper: Centre for the Development of Human Initiatives, India; Institute of Environmental Studies and Wetland Management, Department of Environment, Government of West Bengal, India; Research Institute for Aquaculture No.1, Vietnam; Centre for Environmental Management and Participatory Design, West Bengal, India; South China Agricultural University, China; Centre for Environment and Society, University of Essex, UK; Roskilde University, Denmark; FishBase Information and Research Group, The Philippines, and; Department of Applied Social Science, University of Stirling, UK. The research leading to these results has received funding from the European Community's Seventh Framework Programme FP7-ENrv-2007-1 under grant agreement $n^{\circ} 213015$. This publication reflects the authors' views, and the European Community is not liable for any use that may be made of the information contained herein. E. Brooks was supported by a $B B S R C$ doctoral grant and funding from her CASE partner IUCN. We would also like to thank two anonymous reviewers for their constructive comments. 


\section{LITERATURE CITED}

Balmford, A., A. Bruner, P. Cooper, R. Costanza, S. Farber, R. E. Green, M. Jenkins, P. Jefferiss, V. Jessamy, J. Madden, K. Munro, N. Myers, S. Naeem, J. Paavola, M. Rayment, S. Rosendo, J. Roughgarden, K. Trumper, and R. K. Turner. 2002. Economic reasons for conserving wild nature. Science 297:950-953. http:// dx.doi.org/10.1126/science. 1073947

Bateman, I. J., G. M. Mace, C. Fezzi, G. Atkinson, and R. K. Turner. 2011. Economic analysis for ecosystem service assessments. Environmental and Resource Economics 48:177-218. http://dx.doi.org/10.1007/s10640-010-9418-x

Béné, C., E. Steel, B. K. Luadia, and A. Gordon. 2009. Fish as the "bank in the water" - evidence from chronic-poor communities in Congo. Food Policy 34:108-118. http://dx.doi.org/10.1016/j. foodpol.2008.07.001

Chee, Y. E. 2004. An ecological perspective on the valuation of ecosystem services. Biological Conservation 120:549-565. http:// dx.doi.org/10.1016/j.biocon.2004.03.028

Christie, M., I. Fazey, R. Cooper, T. Hyde, and J. O. Kenter. 2012. An evaluation of monetary and non-monetary techniques for assessing the importance of biodiversity and ecosystem services to people in countries with developing economies. Ecological Economics 83:67-78. http://dx.doi.org/10.1016/j.ecolecon.2012.08.012

Collares-Pereira, M. J., and I. G. Cowx. 2004. The role of catchment scale environmental management in freshwater fish conservation. Fisheries Management and Ecology 11:303-312. [online] URL: http://onlinelibrary.wiley.com/doi/10.1111/ j.1365-2400.2004.00392.x/full

Cowling, R. M., B. Egoh, A. T. Knight, P. J. O'Farrell, B. Reyers, M. Rouget, D. J. Roux, A. Welz, and A. Wilhelm-Rechman. 2008. An operational model for mainstreaming ecosystem services for implementation. Proceedings of the National Academy of Sciences 105:9483-9488. http://dx.doi.org/10.1073/pnas.0706559105

Daw, T., K. Brown, S. Rosendo, and R. Pomeroy. 2011. Applying the ecosystem services concept to poverty alleviation: the need to disaggregate human well-being. Environmental Conservation 38:370-379. http://dx.doi.org/10.1017/S0376892911000506

de Groot, R., L. Brander, S. van der Ploeg, R. Costanza, F. Bernard, L. Braat, M. Christie, N. Crossman, A. Ghermandi, L. Hein, S. Hussain, P. Kumar, A. McVittie, R. Portela, L. C. Rodriguez, P. ten Brink, and P. van Beukering. 2012. Global estimates of the value of ecosystems and their services in monetary units. Ecosystem Services 1:50-61. http://dx.doi. org/10.1016/j.ecoser.2012.07.005

Dugan, P., A. Delaporte, N. Andrew, M. O'Keefe, and R. L. Welcomme. 2010. Blue harvest: inland fisheries as an ecosystem service. WorldFish Center, Penang, Malaysia. [online] URL: http://www.unwater.org/downloads/Blue Harvest.pdf

Farber, S. C., R. Costanza, and M. A. Wilson. 2002. Economic and ecological concepts for valuing ecosystem services. Ecological Economics 41:375-392. http://dx.doi.org/10.1016/S0921-8009(02) $\underline{00088-5}$

Graves, A., J. Morris, J. Chatterton, A. Angus, J. Harris, M. Potschin, and R. Haines-Young. 2009. Valuation of natural resources: a NERC scoping study. Natural Resources Management Centre, Cranfield University, Bedford, UK.

Haukoos, J., and R. Lewis. 2005. Advanced statistics: bootstrapping confidence intervals for statistics with "difficult" distributions. Academic Emergency Medicine: Official Journal of the Society for Academic Emergency Medicine 12(4):360-365.

Hein, L., K. van Koppen, R. S. de Groot, and E. C. van Ierland. 2006. Spatial scales, stakeholders and the valuation of ecosystem services. Ecological Economics 57:209-228. http://dx.doi. org/10.1016/j.ecolecon.2005.04.005

Hicks, C. C., T. R. McClanahan, J. E. Cinner, and J. M. Hills. 2009. Trade-offs in values assigned to ecological goods and services associated with different coral reef management strategies. Ecology and Society 14(1): 10. [online] URL: http:// www.ecologyandsociety.org/vol14/iss1/art10

International Union for Conservation of Nature (IUCN). 2000. Vision for water and nature. A world strategy for conservation and sustainable management of water resources in the 21 st Century. IUCN, Gland, Switzerland and Cambridge, UK.

Jenkins, W. A., B. C. Murray, R. A. Kramer, and S. P. Faulkner. 2010. Valuing ecosystem services from wetlands restoration in the Mississippi Alluvial Valley. Ecological Economics 69:1051-1061. http://dx.doi.org/10.1016/j.ecolecon.2009.11.022

Kaffashi, S., M. N. Shamsudin, A. Radam, M. R. Yacob, K. A. Rahim, and M. Yazid. 2012. Economic valuation and conservation: do people vote for better preservation of Shadegan International Wetland? Biological Conservation 150:150-158. [online] URL: http://www.sciencedirect.com/science/article/pii/ S000632071200136X

Martín-López, B., C. Montes, and J. Benayas. 2007. Influence of user characteristics on valuation of ecosystem services in Doñana Natural Protected Area (south-west Spain). Environmental Conservation 34:215-224. http://dx.doi.org/10.1017/S0376892907004067

Millennium Ecosystem Assessment (MEA). 2005. Ecosystems and human well-being: synthesis. Island, Washington, D.C., USA.

Plummer, M. L. 2009. Assessing benefit transfer for the valuation of ecosystem services. Frontiers in Ecology and the Environment 7 (1):38-45. http://dx.doi.org/10.1890/080091

Reed, M. S. 2008. Stakeholder participation for environmental management: a literature review. Biological Conservation 141:2417-2431. http://dx.doi.org/10.1016/j.biocon.2008.07.014

Rouquette, J. R., H. Posthumus, D. J. G. Gowing, G. Tucker, Q. L. Dawson, T. M. Hess, and J. Morris. 2009. Valuing natureconservation interests on agricultural floodplains. Journal of Applied Ecology 46:289-296. http://dx.doi.org/10.1111/ j.1365-2664.2009.01627.x

Sachs, J. D., J. E. M. Baillie, W. J. Sutherland, P. R. Armsworth, N. Ash, J. Beddington, T. M. Blackburn, B. Collen, B. Gardiner, K. J. Gaston, H. C. J. Godfray, R. E. Green, P. H. Harvey, B. House, S. Knapp, N. F. Kümpel, D. W. Macdonald, G. M. Mace, J. Mallet, A. Matthews, R. M. May, O. Petchey, A. Purvis, D. Roe, K. Safi, R. K. Turner, M. Walpole, R. Watson, and K. E. Jones. 2009. Biodiversity conservation and the Millennium Development Goals. Science 325:1502-1503. http://dx.doi.org/10.1126/science.1175035 
Skourtos, M., A. Kontogianni, and P. A. Harrison. 2010. Reviewing the dynamics of economic values and preferences for ecosystem goods and services. Biodiversity and Conservation 19:2855-2872. http://dx.doi.org/10.1007/s10531-009-9722-3

Springate-Baginski, O., D. J. Allen, and W. R. T. Darwall, editors. 2009. An integrated wetland assessment toolkit: a guide to good practice. IUCN, Gland, Switzerland and Cambridge, UK. [online] URL: http://data.iucn.org/dbtw-wpd/edocs/2009-015. pdf

Tallis, H., P. Kareiva, M. Marvier, and A. Chang. 2008. An ecosystem services framework to support both practical conservation and economic development. Proceedings of the National Academy of Sciences 105(28):9457-9464. http://dx.doi. org/10.1073/pnas.0705797105

The Economics of Ecosystems and Biodiversity (TEEB). 2008. The Economics of Ecosystems and Biodiversity: an interim report. European Commission, Brussels, Belgium. [online] URL: http:// www.teebweb.org/wp-content/uploads/Study $\% 20$ and $\% 20$ Reports/ Additional $\% 20$ Reports/Interim $\% 20$ report/TEEB $\% 20$ Interim $\%$ 20Report English.pdf

The Economics of Ecosystems and Biodiversity (TEEB). 2012. The Economics of Ecosystems and Biodiversity: ecological and economic foundations. P. Kumar, editor. Routledge, New York, New York, USA.

Van der Ploeg, S., and R. S. de Groot. 2010. The TEEB Valuation Database - a searchable database of 1310 estimates of monetary values of ecosystem services. Foundation for Sustainable Development, Wageningen, The Netherlands. [online] URL: http://www.fsd.nl/esp/80763/5/0/50

Vermeulen, S., and I. Koziell. 2002. Integrating global and local values: a review of biodiversity assessment. International Institute for Environment and Development, London, UK.

Vigerstol, K. L., and J. E. Aukema. 2011. A comparison of tools for modeling freshwater ecosystem services. Journal of Environmental Management 92:2403-2409. http://dx.doi.org/10.1016/ j.jenvman.2011.06.040

Yiming, L., S. Chunrong, F. Sugden, L. Shiming, C. Fengbo, W. Wenzhong, J. Baoguo, G. Min, L. Huashou, and Y. Yanqiong. 2010. Report on livelihoods dependent on highland aquatic resources - a case study at Shaoguan, China. HighARCS WP4 report. South Agricultural University, Guangzhou, China.

Zander, K. K., and S. T. Garnett. 2011. The economic value of environmental services on indigenous-held lands in Australia. PLoS ONE 6(8):e23154. http://dx.doi.org/10.1371/journal. pone. 0023154 
Appendix 1. Site descriptions of the HighARCS projects.

\section{Shaoguan, China}

The site incorporates three fishing communities along the Beijiang (Pearl River catchment) river, upstream and downstream of the city of Shaoguan in Guangdong Province, southern China. The livelihoods of fishing communities are declining due to the decrease of fishing resources, and the marginalization by policies neglecting the fishing community. Aquatic resources and other ecosystem services are declining mainly due to the impacts of dams, industrial scale sand dredging of the river bed, and water pollution from industrial sources.

\section{Buxa, West Bengal, India}

The project site is in the forested hills of the Jalpaiguri District in West Bengal, India and incorporates three villages, all of which are within the Buxa Tiger Reserve (BTR) the core of which is a National Park. Most of the people living within the BTR are poor and rely upon agriculture which is supplemented by animal husbandry, manual labor and the use and selling of non-timber forest products. The site is rich in biodiversity including many globally threatened species and has more than ten rivers, which together supply important ecosystem services to the local communities. As Buxa is within a Forest Reserve (BTR) governance regarding resource use and management is strongly influenced by the Department of Forestry, which often leads to conflicts with local communities' use of natural resources.

\section{Dakrong Highland Commune, Quang Tri, Vietnam}

The site incorporates three communities along the Dakrong River, in the hills of central Vietnam in Quang Tri Province. Within the three communities it is the poorest households that are more dependent upon aquatic resources as they have more limited access to good agricultural land, and the river provides water and power through microgenerators to all in the villages. However aquatic resources at the site are declining due to the impacts of hydropower dams, deforestation, gold mining and overfishing which is impacting the livelihoods of the communities. The legal framework governing aquatic resources and biodiversity is also complex with a range of overlaps between legislation, policies and institutions, and suffers from a lack of guidance and poor capacity for implementation on the ground.

\section{Phu Yen District, Son La, Vietnam}

The site includes a number of communes along the Song Da Reservoir (dammed in 1979) in the mountains of eastern Son La province, northern Viet Nam. Many of these communities are poor whose livelihoods are highly dependent upon fishing and harvesting aquatic resources. However, the aquatic resources and other ecosystem services in this area are declining due to policies driving economic development (including historic and future dam development), intensification of agriculture in the upper catchment, illegal and destructive fishing practices, aquaculture and fisheries development in the reservoir, the introduction of non-native invasive species, and the operation of the Hoa Binh dam being principally for power generation (i.e. with little regard to its knock on affects). 
Appendix 2. Site specific ecosystem service selection.

Table A2.1. Aquatic ecosystem services used at each site, and included in site-specific stated preference valuation.

\begin{tabular}{|c|c|c|c|}
\hline Shaoguan & Buxa & Quang Tri & Son La \\
\hline $\begin{array}{l}\text { Agricultural water } \\
\text { supply }\end{array}$ & $\begin{array}{l}\text { Daily water use } \\
\text { (humans) }\end{array}$ & $\begin{array}{l}\text { Commercial } \\
\text { fishing/shrimping }\end{array}$ & $\begin{array}{l}\text { Commercial } \\
\text { fishing/shrimping }\end{array}$ \\
\hline $\begin{array}{l}\text { Domestic water } \\
\text { supply }^{\dagger}\end{array}$ & $\begin{array}{l}\text { Daily water use } \\
\text { (animals) }\end{array}$ & $\begin{array}{l}\text { Subsistence } \\
\text { fishing/shrimping }\end{array}$ & $\begin{array}{l}\text { Subsistence } \\
\text { fishing/shrimping }\end{array}$ \\
\hline $\begin{array}{l}\text { Industrial water } \\
\text { supply }^{\dagger}\end{array}$ & Rainfall & $\begin{array}{l}\text { Daily water use } \\
\text { (humans) })^{\dagger}\end{array}$ & Daily water use (humans) ${ }^{\dagger}$ \\
\hline Aquatic products & Cleaning pollution & $\begin{array}{l}\text { Daily water use } \\
\text { (livestock) }\end{array}$ & Daily water use (livestock) \\
\hline Sand & Flood control & Water for gold mining & Agricultural water supply ${ }^{\dagger}$ \\
\hline Transportation & Subsistence fishing & Gold mining & Transportation \\
\hline Hydropower & Commercial fishing & Transportation & Hydropower \\
\hline Fishing & Sand and stone & Hydropower & $\begin{array}{l}\text { Wetland water storage } \\
\text { during dry season }\end{array}$ \\
\hline $\begin{array}{l}\text { Air moisture } \\
\text { regulation }\end{array}$ & Medicinal plants & $\begin{array}{l}\text { Wetland water storage } \\
\text { during dry season }\end{array}$ & Flood control \\
\hline $\begin{array}{l}\text { Air temperature } \\
\text { regulation }\end{array}$ & $\begin{array}{l}\text { Habitat provision } \\
\text { for animals }\end{array}$ & Flood control & Water purification \\
\hline Flood control & Tourism & Water purification & $\begin{array}{l}\text { Habitat provision for } \\
\text { economic species } \\
\text { (fish/shrimp) }\end{array}$ \\
\hline Disease reduction & Transportation & $\begin{array}{l}\text { Habitat provision for } \\
\text { animals }\end{array}$ & Climate regulation \\
\hline Clean environment & $\begin{array}{l}\text { Basic health } \\
\text { services }\end{array}$ & Biodiversity & Biodiversity protection \\
\hline Cleaning pollution & Education & Tourism & $\begin{array}{l}\text { Maintain genetic resources } \\
\text { of valuable fish }\end{array}$ \\
\hline Biodiversity & $\begin{array}{l}\text { Skill based training } \\
\text { for livelihoods }\end{array}$ & Recreation & Tourism \\
\hline Sailing ${ }^{\ddagger}$ & $\begin{array}{l}\text { Research on aquatic } \\
\text { resources }\end{array}$ & Aesthetic value & Recreation \\
\hline Tourists & $\begin{array}{l}\text { Research of } \\
\text { renewable energy }\end{array}$ & Spiritual value & Aesthetic value \\
\hline Swimming $^{\ddagger}$ & Biodiversity & Research & Spiritual value \\
\hline $\begin{array}{l}\text { Living environment } \\
\text { for boat people }\end{array}$ & Stable environment & Education & Research \\
\hline Aesthetic value & & & Education \\
\hline Spiritual value & & & \\
\hline Education & & & \\
\hline Research & & & \\
\hline
\end{tabular}

${ }^{\dagger}$ Averaged to produce water supply score

${ }^{\ddagger}$ Averaged to produce recreation score

$\S$ Averaged to produce fisheries score 